\title{
The Impact of Shari'ah on Human Security
}

\author{
Dr. Mustapha Isa Qasim. \\ mustaphaisaqasim@gmail.com \\ $+2348035907922 / 2348076400839$ \\ Department Of Arts And Social Science Education (Islamic Studies Section) Ahmadu Bello University, Zaria. \\ Nigeria
}

\begin{abstract}
Shari'ah is the Divine Law which caters for all human needs at all times and places. This paper touched the fundamental areas that Shari'ah protects: Religion, Life, Wealth, Intellect and Progeny. It emphasized the protection of life through legal action called Qisas (Equitable retaliation) in line with the saying of Allah (S.W.T.) in the Glorious Qur'an. The wisdom behind Qisas is to secure the society against crime, establish justice among all members of the society and to purify the culprit from the crime he has committed so as to serve as deterrent to others, thereby sanitizing the society in general. Therefore Shari'ah should be implemented in human life because it is the only source for human security.
\end{abstract}

\section{Introduction}

In the Name of Allah the Beneficent, the Merciful. Peace and Blessings of Allah be Upon His Messenger Muhammad (SAW) his family, Companions and those who follow their Guidance up to the last Hour.

The life of human being on earth is based on Divine guidance from Allah the creator, sustainer and owner of all that is in the earth and Heaven. Although man could develop the courage and wisdom to provide a law for himself to guide his life, but the level of his thinking and knowledge is grossly inadequate to provide a suitable and equitable code-of conduct which enables him to lead a ssuccessful life here and in the hereafter. In view of this, Allah, the most high is in the best position to provide a permanent law to guide all human beings. This is what is contained in His Devine law called the shari'ah.

\section{Definition of Shari'ah}

Shari'ah is defined by different scholars, some of which are the following:

According to Abu-Amina, B. (1990) "Shari'ah refers to the sum total of Islamic laws which were revealed to the Prophet Muhammad (SAW) and which are recorded in the Qur'an as well as deducible from the Prophet divinely-guided lifestyle called the Sunnah"

Ibrahim,Y.( (2004)says;YY "Shari'ah is the clear path (religion) prescribed by Allah (the most high) for His servants to follow in order to be free and safe from the abyss of despair in this world and the next to come".

In a general term, shariah refers to the whole legal code of Islam which provisions and are as law seen as an expression of the totality of the Islamic way of life which Muslims universally are bound to adopt and follow.

Allah (SWT) says:

"Then we put you on a straight path (Shari'ah) in your affairs, so follow it and do not follow the desires of those who have no knowledge (Q. 45:18)

\section{Objectives of Shari'ah}

Shari'ah is prescribed for man to help him achieve his spiritual and mundane objectives. Therefore, Shari'ah is designed to protect five fundamental areas of human life: religion, intellect, soul, wealth (property) and progeny (posterity).

Religion (Din) Islam ordains that there is no compulsion in religion (2:256). No one is forced to accept another person's faith and the religion of other people is protected in Islam. In fact, it is an offence in Islam to pull down churches or synagogues and to despair a religious people without a genuine reason. Islam perfectly grants "religious freedom and the Shari'ah is protecting all religions e.g. jihad is waged against non-Muslims in order to protect Islam from aggression, not to kill non-Muslims. Similarly, the punishment of Riddah(Apostasy) is to protect the sanctity of Islam from corruption.

\section{Intellect (Aqal)}

Intellect is the power of mind to reason which normally distinguishes man from animals. This power of mind is best protected by the Shari'ah,e.g. the prohibition of alcohol. Man has full knowledge that alcoholism or 
wine consumption is harmful, but he deliberately takes it as a way of life. Any substance which causes intoxication is prohibited in-Islam.

Soul (Nafs)

Shari'ah prohibits killing of a soul without genuine reason. It has taken all necessary measures to protect human soul irrespective of their beliefs:

And do not kill the soul (i.e., person) which Allah has forbidden, except by right. And whoever is killed unjustlywe have given his heir authority, but let him not exceed limits in (the matter of) taking life. Indeed, he has been supported (by the law). (17:33)

The punishment of Murder in Islam is to execute the culprit.

"And there is (a saving of) life for you in al-Qisas (the law of equality in punishment), O men of understanding, that you may become righteous" (2:179).

\section{Wealth or property $(\mathrm{Mal})$}

Wealth is so dear to human being therefore it should not be taken away from him except with a genuine reason.

The Shari'ah, therefore, protects properties of individuals.

Allah (SWT) says:

And do not consume one another's wealth unjustly or send it (in bribery) to the rulers in order that (they might aid) you (to) consume a portion of the wealth of the people in sin, while you know (it is unlawful). (2:188)

\section{Progeny or Posterity (Nasl)}

For the continuity of human specy, the Shari'ah makes it one of its aims and objectives to protect man's posterity. This is the philosophy behind the prohibition of Zina in Islam.

\section{Nature of Shari'ah}

The nature of Shari'ah is entirely different from all man-made laws. It is a divine law which takes care of all human needs, and it is a universal law which admits no difference between man and man except in faith. Another characteristic of this law is eternal. It is not based on a particular race or period of human history. It is designed for all ages. The laws contained in the Shari'ah are full of wisdom and justice, no aspect of it is designed to harm or cheat any of Allah's creatures because it is mercy to all.

The practical application of Shariah through which the required human security is achieved is by the use of Qisas. $Q$ isas is an Arabic word which means tracking the footsteps "like in the case of Prophet Musa (A.S) where Allah (SWT) says:

"Moses said: "That was what we were seeking after: so they went back on their footsteps, following (the path they had come) (18:64).

Technically, Qisas means "the act or a similar act which a victim or his next of kin does to a culprit. It has also been defined as "doing to the criminal the same thing that has been done to the victim, be it murder, amputation or wound. Allah (SWT) says:

"And we ordained for them therein a life for a life, an eye for an eye, a nose for a nose, an ear for an ear, a tooth for a tooth and for (other) injuries equitable retaliation" (5:54)

In another verse, Allah(S.W.T.) says:

O ye who believe! the law of equality is prescribed to you in cases of murder; the free for the free the slave for the slave the woman for the woman. But if any remission is made by the brother of the slain then grant any reasonable demand and compensate him with handsome gratitude; this is a concession and a Mercy from your Lord. After this whoever exceeds the limits shall be in grave penalty.

We can therefore say that Qisas is equitable retaliation or law of equality. It is the method used in the shari ah for establishing justice among people.

\section{Rationale behind Qisas punishment}

In Islamic law, all commands and prohibitions are behind a great deal of wisdom, because they are from Allah the most learned and wise. The most apparent wisdom is indicated in the following verse.

"And there is (a saving of) life for you in al-Qisas (the law of equality in punishment), $O$ men of understanding, that you may become righteous" (2:179).

Among others, the rationale behind the institution of of Qisas punishment include securing society against crime.Implementing the law of Qisas without doubt, protects the individual and society against crime because it makes people aware of other people's rights and provides a solid foundation for maintaining peace 
and security in society. Also,Qisas is meant to establish justice among all members of society so that no one would dare assault others due to his high social standing, wealth or power, for all members of society are on equal footing before the law.

In Islam, punishment is to be inflicted only upon the culprit, as the Qur'an clearly states: “.... No bearer of burdens can bear the burden of another" (6:164). Therefore no any person is to be punished except the criminal, and the punishment should be inflicted according to the crime he committed in the same way he inflicted the victim, this provides total justice in Islamic law.

In order to take account of the psychological state of the victims' relatives, Allah (SWT) has given authority to the relatives of the victim over the culprit in order to remove ill-feelings. Allah (SWT) says:

"And whomever is killed wrongfully-We have given his heir authority (to demand qisas or to forgive), but let him not exceed limits in (the matter of) taking life, for he is helped (by the law) (17:33)

By implementing the law of Qisas, the culprit is purified and cleansed of the crime he has committed, for Allah is so just that He does not punish him twice (in this life and the hereafter) once he has repented of his sin. The essential significance of the Qisas punishment is to recognize the holiness of the judgment that is from Allah (SWT), no any other judgment is above it and it is full of wisdom and justice. Muslim is therefore submissive to it in totality. Allah says:

"Say, truly my prayers and all my service of sacrifice, my life and my death are (all) for Allah the cherisher of the worlds $(6: 162)$

The significance of Qisas could also be seen vividly in the tradition of the Prophet (SAW) which says:

"Implementing one of Allah's laws of punishments is better than all the rainfall for forty days in the land of Allah the Almighty" Reported by Ahmad in Al-Musnad 14/351.

The implementation of Qisas punishment brings peace and security in society. Take a look at Saudi Arabia for example, the country is in peace and security, people are engaged in developing the country, quite assured that their blood, property and honour are safe. A person can safely travel north, south, east or west without fear of molestation. In this way, the country is a good example in the world where fewer crimes are committed.

\section{Method of Implementing Qisas}

Once somebody is killed, the punishment, according to Qur'an is: life for life" i.e the culprit should be killed in the same way. The family of the deceased has the option either to receive diyyah (Blood) money from the culprit, or he should be killed. Once the diyyah is collected, the culprit should not be killed. This is a mercy to the Ummah of the Prophet (SAW) as indicated by Abdullahi bin Abbas (R.A) that: Qisas was prescribed for the children of Israel, but the diyyah (blood money) was not ordained for them (Bukhari).

Al-Jaza'ri A.J (1978),mentioned that:The full diyyah (blood money) for killing a soul is one hundred (100) camels or its equivalent, 1000 gold's weight or 2000 diamond or 200 cows or 1000 goats/sheep. The diyyah equivalent in Nigerian currency for 2011/2012 is $\$ 31,047,099.00$.

Full diyyah is equally paid for removing any of the sensory organs, two ears, eyes, hands legs or cutting off nose, tongue or private parts.teh Prophet (SAW) wrote to his governors that if anyone cuts off somebody's nose full mistakenly, full diyyah on a person who heats another person and if deformed the victim's hearing, seeing, sense and sexual ability, the culprit was ordered to pay four(4) full diyyah.

Also, half diyyah is paid for cutting off one ear, eye, hand, or leg. In the case of removing one finger, 10 camels are paid, $3 \frac{112}{2}$ camels for finger-joint. The Prophet (SAW) said:

For each finger of hand and leg, ten camels are paid, and for removing a tooth, five camels are paid (Tirmidhi) For wounds injury or infliction on any part of human body, should be settled through Qisas as indicated in the Qur'an ...

"And wounds equal for equal" (Q5:54)

\section{Conclusion}

Shari'ah is the embodiment of Islamic law. It is designed by Allah (SWT) to cater for all human needs in this world and to pave way for the next world. Qisas is a fundamental aspect of the Shari'ah especially in providing equitable judgment among people and for saving human life. The provision of the Shari'ah on equitable retaliation for killing somebody is the only way to save human soul in any given society. It is therefore obvious that the problems we face in Nigeria of insecurity, tribal, ethnic and religious crisis is due to lack of proper implementation of the provisions of the law, and could be solved by appropriately punishing the culprits without fear or favor. 


\section{References}

[1]. Abdul-Rahman.,The Basis of Shari'ah,. Gaskiya Corporation, Zaria-Nigeria,1981.

[2]. Abu-Amina, B., The Evaluation of Fiqh, International Islamic Publishing House, Riyad, Saudi Arabia,1990.

[3]. Ali, Y.A., The Holy Qur'an, Amana Corporation, Jedda, Saudi Arabia,1983.

[4]. Al-Jaza'ri A.J., Minhaj-al-Muslim, Beirut-Lebanon, 1978.

[5]. El-Awa, M.S., Punishment in Islamic law. American Trust Publication, U.S.A., 1978.

[6]. Ibrahim, Y.Y., Shari'ah and Muslims in Nigeria, Garkuwa Media Services, Sokoto-Nigeria, 2004.

[7]. Maududi, A.,The Meaning of the Qur'an, London, U.K, 1982.

[8]. Sabiq, S., Fiqh al-Sunnah, Beirut-Lebanon, 1983.

[9]. Sabuni, M.A.,Tafsir Ayat al-Ahkam, Dat al-Sabuni, Egypt,1999. 